\title{
МАС-МЕДІА Й ІДЕНТИЧНІСТЬ: ПРОБЛЕМИ ТА ВИКЛИКИ СЬОГОДЕННЯ (СУБ'ЄКТНО-ВЧИНКОВИЙ ВИМІР)
}

Кальба Я. С.

\section{ВСТУП}

Початок XXI ст. характеризується зростанням актуальності медіа як індустрії, що торкається ментальності кожної людини. Сучасність немислима без медіа-світу. Однак доступність, мобільність інформації почасти звужують пізнавальний інтерес молоді до системного навчання, а надмірне занурення у віртуальний світ породжує різні психо-невротичні акцентуації, продукує новий онтичний цикл, у якому складно розпізнати загальнолюдську ідентичність. Зростає негативний, агресивний контент. Влада, достаток опановують світом, ув'язнюють духовний, душевний потенціал молодої людини, тиражуючи задоволення, насильство, збагачення. Культ успіху стає фантомним ідеалом мас.

Науковці задаються питанням - що первинне: новина чи соціальна дія? Чи то новини містять так багато насилля, бо світ такий жорстокий, чи то світ стає жорстоким від таких новин? Британський філософ К. Поппер зазначає, що не існує інформації в чистому вигляді, іншими словами, інформація несе в собі якусь тенденцію. Мовиться про те, що різниці між словами «інформувати» й «виховувати» немає і бути не може. А тому вплив мас-медіа не обмежується інформуванням: ЗМІ стають і «вихователями», «агітаторами», «пропагандистами». Тож індивідуальний, суб'єктний вибір молодої людини, вільне волевиявлення стає лише наслідком формування та лобіювання мас-медіа «образу світу», що відображає уніфіковані, соціально очікувані форми світосприйняття, світотворення (достатньо пригадати той факт, що лави угрупування скінхедів поповнилися майже втричі після масового перегляду фільмів «Ромпер Стомпер», «Американська історія «Х»).

Вочевидь, медіа-контент впливає на людину як суб'єкта психічної активності, на свободу конструювання власної ідентичності. Йдеться про потенційну екзистенційну автономність, імовірний автентичний спосіб буття молодої людини, такий, що відповідав би внутрішній сутності, душевно-духовній природі іiі «Я». Якщо суб'єктний підхід (С. Рубінштейн) виокремлює в людині самостійність, самодостатність, авторське начало тощо, а вчинковий підхід 
(В. Роменець) робить наголос на значенні для неї стосунків із іншими людьми, із соціумом і його культурними цінностями, то суб'єктновчинковий підхід (В. Татенко) передбачає творче поєднання цих двох сутнісних диспозицій, притаманних людській природі.

А тому вельми актуально говорити про мас-медіа в контексті суб'єктно-вчинкової спрямованості контенту, можливості актуалізувати морально-етичний, душевно-духовний вимір людської ідентичності, ii авторське право на самотворення як суб'єкта вчинкового поступу, що видається логічним і послідовним щодо Концепції гуманітарного розвитку України - 2020.

Тож мета нашої роботи - дослідити соціально-психологічну генезу масових феноменів, з'ясувати, наскільки усвідомлює молода людина власну причетність до медіа-культури (як споживач і як носій медіаінтроектів), яку «активну позицію-відповідь» демонструє вона щодо «медіа-тексту» сьогодні та як це корелює з ії суб'єктно-вчинковою зрілістю, змістовими, статусно-рольовими характеристиками іiі ідентичності.

\section{1. Мас-медіа, мас-медійні феномени: до проблеми визначення і впливу}

Теоретична і практична сторони заявленої проблеми вимагають насамперед уточнення дефініцій вихідних понять: «медіа», «масмедіа», «медіалізація», «маси», «масифікація», «соціальна телепатія» тощо.

Media (від лат. medium - засіб, спосіб) - засоби та інструменти зберігання і передачі інформації та даних. Часто як синоніми вживають ЗМІ, ЗМК, мас-медіа тощо. До медіа зараховують засоби зв'язку і передачі інформації різних типів - від найдавніших (мови жестів, наскельних малюнкыв) до найсучасніших, які утворюють глобальні інформаційні супермагістралі. Коли медіа використовують для одночасної комунікації з тисячами людей, з'являється поняття «масмедіа» (зі своїми специфічними атрибутами та функціями), що об'єднує пресу, радіо, телебачення й рекламу.

У своїх працях 3 теорії комунікативістики канадський філософ М. Маклюен умовно розділив історію людства через трансформацію систем медіа, увівши поняття «Галактика Гутенберга», тобто світ друкованих медіа, який панував із винайденням друкарського верстата, та світ, що з'явився 3 ерою електронних медіа, коли періодика поступилася популярністю радіо й телебаченню. Із приходом ери Інтернету усталені підходи до класифікації медіа почали поступово трансформуватися. Нині існує поділ на традиційну періодику (газети, журнали), нові аудіовізуальні ЗМІ (радіо, телебачення) й онлайн-медіа 
(інтерактивні медіа). Такі підходи пов'язані 3 домінуванням інтерактивного діалогу та поширенням користувацького контенту, котрий виходить за межі тлумачення $3 \mathrm{MI}^{1}$.

До головних ознак цифрових медіа, окрім означених (мультимедійності, гіпертекстуальності та інтерактивності), належать генерування інформації в режимі реального часу, персоналізація іiі доставки споживачеві, можливість користувача брати участь у іiі творенні, впливати на процес колективної медіатворчості. Саме цими ознаками нові медіа відрізняються від традиційних ЗМІ. Загальною характеристикою їх $\epsilon$ орієнтація на максимальну взаємодію (інтеракцію) користувачів у віртуальному інтернет чи мобільному середовищах. Дослідники визначають онлайн-медіа як групу інтернетдодатків і сервісів, побудованих на ідеології та технології Web 2.0, що дають можливість створювати й обмінюватися контентом користувачів. Типовою $є$ класифікація, яка відображає основні елементи онлайн медіа: блоги, соціальні мережі (Facebook, Twitter), спільні проекти (Wikipedia), контентні спільноти (YouTube), віртуальні соціальні світи (SecondLife), віртуальні ігрові світи (World of Warcraft) тощо ${ }^{2}$.

Отож, трансформація медіа відбувалася на цивілізаційному зламі, коли на зміну індустріальному прийшло постіндустріальне (інформаційне) суспільство. Воно стало новим етапом розвитку соціуму, а інформаційно-комп'ютерна революція - процес інформатизації всіх сфер життя (суспільства загалом і людини зокрема) - його квінтесенцією.

Систематичне вивчення масових феноменів розпочалося у другій половині XIX ст. у країнах Західної Європи, незалежно одна від одної сформувалися дві наукові школи: німецька психологія народів (М. Лазарус, Г. Штейнталь, В. Вундт) і франко-італійська психологія мас (Г. Лебон, Г. Тард, Г. Моска, В. Парето, Ш. Сігеле). Більшість істориків вважають, що обидві школи виконували соціальні замовлення політичної еліти своєї країни. Так, Німеччина, яка не володіла колоніями як Франція чи Іспанія і Португалія, відчувала епоху боротьби за перерозподіл світу, тому німецькі лінгвісти й етнографи розпочали детальне дослідження мов, культури й міфології первісних народів, намагаючись 3'ясувати їхні психологічні особливості, національний дух і колективне несвідоме. Французьку ж еліту тоді цікавив зростаючий у країні революційний рух: революції відбувалися одна за одною, терор i руйнації щоразу зростали. Тому вчені

${ }^{1}$ Bruhn K., Denesi M. Dictionary of Media and Communication. New York, 2009. P. 207.

2 Там само. Р. 233-236. 
зосередилися насамперед на вивченні властивостей мас, механізмах колективної агресії тощо. Завдання полягало в тому, аби для початку довести антисоціальну, антигуманну й деструктивну сутність людської маси як такої (в їх постулатах ще поняття маси i натовпу синонімізуються); а також забезпечити інструментарій для дієвих маніпуляцій масою ${ }^{3}$.

На пострадянському просторі (кінець XIX - початок XX ст.) дослідження масових явищ проводили В. Бехтерєв, П. Блонський, О. Лурія, Д. Узнадзе, вивчаючи сугестивні властивості людини (В. Бехтерєв), психологію установки (Д. Узнадзе), національнокультурні властивості сприймання i мислення (О. Лурія), вплив газетних повідомлень на маси (П. Блонський), циркуляцію чуток ${ }^{4}$

Загалом, одні дослідники відносили понятійний конструкт «маси» та проблему вивчення психології мас до соціології, інші - до соціальної психології, ще інші - до політичної психології, розглядаючи іï концептуальною гілкою тієї чи іншої наукової галузі. Проте причини необхідності володіти знаннями психології мас залишалися сталими: 3 одного боку, прагнення ними управляти, а з іншого - стримувати їх i контролювати.

Неабиякий вплив на розвиток психології мас мали концепції несвідомого 3. Фрейда та К. Юнга. Найвиразніщі риси маси 3. Фрейд пояснював так: «У масі стираються індивідуальні досягнення окремих людей, і тому зникає їхня своєрідність. Расове несвідоме виходить на перший план, гетерогенне губиться в гомогенному, <..> зноситься, знесилюється психічна надбудова, по-різному розвинена в окремих людей, і оголюється (стає дієвим) підсвідомий фундамент, у всіх одинаковий» ${ }^{5}$.

Такими чином, з'являються більші можливості для маніпулювання індивідуальною й масовою свідомістю, зокрема через індивідуальне та масове несвідоме. За К. Юнгом, колективне несвідоме - це психологічна спадщина, котра визначає нашу поведінку й досвід. Її зміст (який автор називав архетипами) - це надособистісні патерни (тобто комплекс, певна констеляція психічних елементів) формування різноманітних способів матеріальної та духовної діяльності в конкретному соціумі. Вивчаючи філогенез несвідомого, К. Юнг дійшов висновку, що в існуванні кожної людини й суспільства присутне, з одного боку, сильне прагнення до відособлення, а 3 іншого - бажання злитися 3 чимось більшим,

3 Психологія мас : навчальний посібник / автор-упор. Я. Кальба. Тернопіль : Навчальна книга Богдан, 2012.

${ }^{4}$ Там само. С. 23.

${ }^{5}$ Фрейд 3. Психоаналитические этюды. Минск : ООО «Попурри», 2001. С. 424. 290 
узагальненим. Як результат, у буденній масовій свідомості завжди переплітаються неусвідомлювані архетипові установки із соціальними стереотипами (схематичні та спрощені уявлення про ті чи інші явища, події, ситуації), головна функція яких - дати швидке знання без докладання власних зусиль. I це легко вдається сучасним медіа, котрі апелюють гучними закликами «ми» (група, сім'я, колектив, держава, планета тощо, адже «я» людини завжди говорить «ми» соціуму: «сила в нас», «ми все зможемо», «за нами правда» тощо $)^{6}$.

Поняття «маси» в науковій літературі розглядали й інші вчені у різних психологічних і соціально-політичних контекстах (Г. Лебон, Г. Моска, С. Московічі, Х. Ортега-і-Гассет, В. Паретто, Ш. Сігеле, Г. Тард). У рамках нашої роботи зупинимося детальніше на одному із сучасних підходів, а саме позиції французького вченого С.Московічі, який розрізняє масу матеріальну і нематеріальну (публіку). Згідно 3 його теорією сучасну масу не видно, проте вона $є$ всюди. Мільйони людей, що спокійно читають газету, мимоволі повторюють радіо- i теленовини, становлять частину нового типу натовпу «нематеріального», розпиленого, який перебуває вдома біля телевізорів, за комп'ютерами тощо. Організація перетворює натовпи у натовпи штучні, комунікація робить із них публіку. Стаючи публікою, люди набувають однакового психологічного стану, котрий С. Московічі характеризує як «супротив розуму, підкорення пристрасті, відкритість до навіювання. Будучи розпорошені, люди однаково поділяють одну й ту саму ілюзію всемогутності, схильні до тих самих перебільшених суджень i емоцій, підвладні одним і тим самим почуттям злості та ненависті, так, якби усі разом вийшли на вулицю для масової маніфестації» ${ }^{7}$.

Розглядаючи питання мас-медіа як інструменту впливу на маси, варто зазначити, що саме останні є обов'язковим адресатом медіавпливів. У такий спосіб мас-медіа роблять даремними зібрання людей, які б інформували та наслідували одне одного. «Віртуальна масифікація XXI століття» не потребує фізичної присутності людей, їх безпосереднього інтегрування; основним засобом єднання людей стає масова комунікація, новітні технології іiі тиражування. Цей інструмент $\epsilon$ засобом т. зв. соціальної телепатії, коли люди починають однаково думати та почувати: велика кількість анонімних індивідів, які ніколи не бачили та не знали один одного, охоплюються тією самою емоцією та

${ }^{6}$ Психологія мас : навчальний посібник / автор-упор. Я. Кальба. Тернопіль : Навчальна книга Богдан, 2012. С. 23.

${ }^{7}$ Московичи С. Век толп. Исторический трактат по психологии масс. Москва : Центр психологии и психотерапии, 1998. С. 238. 
ідеєю, реагують на одну й ту саму музику або гасло, одним словом, перетворюються на єдину колективну істоту ${ }^{8}$.

Саме 3 цього моменту інформаційна функція медіа повністю підмінюється пропагандистською: завуальовано, проте цілеспрямовано пропагувати штучні соціальні переконання, цінності та ідеали. Це спосіб т. зв. «тихого впливу» (прихованого), коли ніхто нікого насильно не примушує i не закликає до активності, проте поступово формує відповідну свідомість, моделі поведінки, спосіб мислення, масовий емоційний фон людей. П. Вінтерхофф-Шпурк пригадує цікавий факт у преамбулі до роздумів про роль медіа. У 1925 р. 3. Фрейду кінематографісти зробили пропозицію щодо співробітництва у створенні фільму про найвідоміші історії кохання. 3. Фрейд не погодився виступити консультантом, коментуючи, що екранізації так само складно уникнути, як і жіночої зачіски «під хлопчика», а тому він особисто нікого не хоче підстригати 9 .

Метафоричний вислів відомого психоаналітика вказував на небезпеку «медіапрепарування» дійсності. Уже на початку XX ст. йому було зрозуміло, що медіа «стрижуть» реалії, спрощують почуття, схематизують складні переживання людей. Натомість особливості медіа-індустрії $є$ непомітними для масової аудиторії, котра звикла сприймати дійсність крізь «медіаокуляри».

«Людина медійна» звикає жити за допомогою опосередкованого досвіду, втрачаючи здатність отримувати безпосередні враження. Вона думає, переживає, приймає рішення на рівні масової, а не індивідуальної свідомості, послуговується не власною феноменальною, а медійною картиною світу. Врешті-решт масифікація неминуча i передбачає використання масового в людині, а саме тих цінностей, норм, установок, імпринтингів, архетипів, які сформувалися у людській психокультурі протягом філогенезу i які й досі відіграють роль латентних мотивів у поведінці окремого індивіда ${ }^{10}$.

Доречним видається пригадати теорію соціальних переконань того ж С. Московічі, що, на думку автора, є унікальною, оскільки поєднує тенденції теорї загальних соціальних феноменів i теорії окремих психічних фрагментів. Цей парадокс зовсім не випадковий. Учений вважає, що в цьому прихована глибинна природа речей: «Суспільство визначається не через просту наявність колективності, яка об'єднує

${ }^{8}$ Кальба Я. Масифікація та її прояви в контексті сучасних телемедіа. Практична психологія та соціальна робота. 2010. № 4. С. 63-64.

9 Винтерхофф-Шпурк П. Медиапсихология. Основные принципы / пер. с нем. Харьков : Изд-во Гуманитарный центр, 2007. С. 185-186.

10 Кальба Я. Масифікація та ії прояви в контексті сучасних телемедіа. Практична психологія та соиіальна робота. 2010. № 4. С. 63. 
людей завдяки ієрархії влади чи завдяки обміну відповідно до інтересів. Зрозуміло, що і влада, й інтереси існують не для того, щоб бути визнаними як такі, суспільству необхідні цінності й переконання, що наповнюють змістом перших. Ці переконання дуже різноманітні: що таке суспільне життя? Яким воно повино бути? Як варто поводитися? Що $є$ справедливим, істинним, прекрасним? I багато іншого, того, що безпосередньо впливає на поведінку людей, на те, ким вони відчувають себе чи в який спосіб обмінюються цінностями. Саме соціальні переконання, об'єднуючи людей, стають певною силою, яка дозволяє їх перетворити на активних членів суспільства, готових брати участь у колективних діях» ${ }^{11}$.

Опираючись на цю теорію, припускаємо, що означені соціальнокогнітивні репрезентації не тільки зумовлюють бачення світу, а й пропагують відповідні моделі поведінки.

На підтвердження цього достатньо пригадати проект вітчизняного телеканалу IHTEP «Великі українці», в якому нам пропонували порівняти Богдана Хмельницького, Тараса Шевченка, Лесю Українку з Миколою Амосовим і Валерієм Лобановським, що $\epsilon$, на думку В. Татенка, «вищою формою маніпулятивного гвалтування української нації за мовчазного спостереження усього цього нами, професійними психологами, котрі точно знають, що індивідуальності не можна порівнювати і приводити до спільного знаменника. Ця процедура нівелює їх, чим досягається вихолощення, знецінення нашої історії, порушення інтимного зв'язку нашого теперішнього з нашим і тільки нашим минулим» ${ }^{12}$.

Отож, для широкого загалу медіа стають механізмом, що уможливлює різнобічні контакти 3 «Великим світом»: когнітивні, емоційні, поведінкові тощо. Сучасні мас-медіа - це не просто мільйонні тиражі чи «сугестори» 3 екранів телевізорів, моніторів (репродукторів). Це нові «контконтрсугестивні» форми й засоби, які викликають довіру, роблять спілкування відкритим, демократичним, але, як наслідок, масифікують психіку. Масмедіа виходять за межі виконання традиційних функцій - інформування, розважання, соціальної інтеграції - та виступають уже не зовнішнім, а внутрішнім чинником психіки людини. Медіа, як вважає М. Маклюен, стають продовженням

11 Московичи С. Социальные представления : исторический взгляд. Психологический журнал. 1995. Т. 16. № 1. С. 3-13.

12 Татенко В. До питання про інтимно-особистісну сферу політичного життя. Проблеми політичної психології та ї̈ роль у становленні громадянина Української держави : збірник наукових праць / заг. ред. М. Слюсаревський та ін. Київ : Міленіум, 2008. Вип. 8. С. 14. 
нервової системи людини, що призводить до перебудови на нейронному рівні ${ }^{13}$.

Один із головних творців постсучасності, британський філософ, соціолог польського походження 3. Бауман зазначає, що за сучасних умов вже йдеться не про час і простір як два окремі виміри буття, а про швидкість і простір. Теорії циклічного і лінійного розуміння часу давно позаду. Сучасна людина живе у фрагментованому часі. Кожен фрагмент має початок, певну тривалість i кінець. На зміну йому приходить наступний фрагмент, і в такій послідовності фрагментів чи епізодів триває наше життя. Це - час, який постійно втікає / «поспішний час» (англ. hurried time C. Бертман), адже тільки-но перед нами виникають можливості, як вони відразу змінюють свою форму. «Текуча сучасність» (liquid modernity) - так вчений змальовує сьогодення, що характеризується фрагментарністю, невпевненістю індивіда й епізодичністю у глобалізованому суспільстві, яке змінюється під впливом технологій. «Текуча сучасність» - це сучасність, що змирилася $з$ крахом власного проекту ${ }^{14}$.

Збуваючи час у компанії, людина зазвичай продовжує активно користуватися мобільним чи ipod, вона продовжує активно обмінюватися повідомленнями, приймати дзвінки, завантажувати інформацію про результати останнього футбольного матчу, дивиться прогноз погоди й загалом ознайомлюватися з тією інформацією, яка йому / ій потрібна. Це вміння multitasking, що сформувалося як відповідь на «тиранію моменту» (Т. Еріксен) - вміння робити кілька речей одночасно. За допомогою цифрових пристроїв людина може водночас дивитися телевізор, приймати повідомлення на мобільному телефоні та читати щось на моніторі комп'ютера. Середньостатистична людина, котра володіє мистецтвом multitasking, може втиснути порядок денний у 7 годин і 5 хвилин, на який іншій людині, щоб його виконати, потрібно 9 годин і 30 хвилин. І ця розбіжність зростає, що, безумовно, впливає як на окремі психічні процеси людини, так і на гомеостаз психічної системи загалом.

Особливий інтерес становлять когнітивні наслідки експансії цифрових комунікацій. Онлайн-медіа формують неосяжний простір із практично необмеженою кількістю видів дискурсу. Людина стає водночас суб'єктом та об'єктом інформаційного впливу, споживачем i виробником інформаційного продукту. Створюючи власний контент,

\footnotetext{
${ }^{13}$ Маклюэн М. Понимание Медиа: Внешние расширение человека / пер. с англ. В. Николаева. Москва : Жуковский : КАНОН-пресс-Ц. 2003. С. 46-47.

14 Bauman Z. The individualized society. Cambridge, Eng. : Polity Press, 2001. P. 176-183.
} 
вона має змогу експлікувати в комунікативних формах екзистенційні переживання різного характеру. Масова комунікація перетворюється на такий собі полілог самовираження і самопрезентації. Особисті сайти, онлайн-щоденники, блоги - усе це результат творчо-репрезентативної активності особистості, котра прагне до публічності. Утім, бути присутнім у соціальній мережі - не завжди означає бути сприйнятим i почутим, адже справжня комунікація відбувається лише у традиційній, діалогічній формі. Людина стає здатною (спроможною) усвідомлювати себе, власну самість у міжсуб'єктному просторі, в діалозі-комунікації.

Звертаючись до діалогічної концепції М. Бахтіна, знаходимо розуміння «діалогу» як зустрічі двох текстів, тексту даного і тексту, який народжується під час сприйняття першого. Текст $є$ вираженням свідомості, об'єктом нашого пізнання, а здатність зрозуміти текст і $€$ правильним «відображенням відображення». «Текст-не річ, а тому іншу свідомість, свідомість того, хто сприймає, ніяк не можна елімінувати або нейтралізувати. Водночас той, хто слухає, сприймає текст, займає стосовно нього активну позицію-відповідь: погоджується чи не погоджується, доповнює, застосовує, виконує. Комунікатор чекає на таке розуміння, чекає відповіді: згоди, співчуття, заперечення, виконання» ${ }^{15}$.

Натомість інформаційні вкидання соціальних мереж $є$ стихійними та неконтрольованими 3 позиції таких комунікативних чинників, як зворотний зв'язок, код, контекст. Тут відбувається розпорошення повідомлень, факти сприйняття / несприйняття яких мають столастичний характер, а сама діяльність користувачів-реципієнтів виходить за межі традиційних пізнавальних практик. Учений iз досліджень Інтернету М. Нельсон підкреслює, що Інтернет сьогодні знаходиться в юнацькому віці, бо стоїть перед вибором, наслідки якого можна буде побачити не зараз, а через 30-50 років ${ }^{16}$.

Дослідження феноменології мас-медіа дозволяє зробити висновок, що останні $є$ неминучим фактором впливу на психіку людини. Транслюючи людству ідеали, цінності, різноманітні фантасмагорії, масмедіа загалом формують людську свідомість і культуру сьогодення, яку, окрім постмодерністської, дедалі частіше називають масовою. Масовою у тому сенсі, що в іiі межах індивідуальне життя починає втрачати сутнісні властивості - автономність, автентичність, духовність, набуваючи незвичних для нього рис масового популізму.

${ }^{15}$ Бахтин М. Эстетика словесного творчества / сост. С. Бочаров ; текст подгот. Г. Бернштейн и Л. Дерюгина ; примеч. С. Аверинцева и С. Бочарова. Москва : Искусство, 1986. С. 385.

${ }^{16}$ Почепцов Г. Від Facebook'y і гламуру до Wikileaks: медіакомунікації. Київ : Спадщина, 2012. С. 52. 


\section{2. Масмедіа й ідентичність як об'єкт дослідження, конструювання}

(за результатами дослідження студентської молоді)

Проблема медіалізації суспільства, вплив медіа на формування свідомості, культури підростаючої особистості стає центром уваги багатьох вітчизняних i зарубіжних вчених (О. Баришполець, О. Вознесенська, Г. Мироненко, М. Кастельс, Л. Найдьонова, Д. Ольшанський, А. Полунін, Г. Почебцов, В. Різун, В. Татенко, О. Голубєва, В. Чалдіні).

У контексті пропонованого дослідження спробуємо дослідити та проаналізувати:

- морально-етичний контент мас-медіа;

- питання експозиції контакту із мас-медіа, зокрема продуктивність часу використання особливості пізнавальних процесів і вольового контролю медіа-користувачів;

- вміння категоризації контенту (фундаментальний когнітивний процес, що дозволяе організувати, структурувати, систематизувати медіа інформацію про навколишній світ), спроможність дефініювати контент, його спрямованість;

- вміння самокатегоризації молодої людини, самоінтерпретації через образи, цінності, вчинки, які в неї викликають бажання ідентифікуватися, а які - бажання бути в опозиції. Іншими словами, з'ясувати, наскільки молода людина усвідомлює та переживає колізію «діалогу-комунікації», якими категоріями як критеріями вона послуговується, сепаруючи інформацію, наскільки іï індивідуальна категоріальна шкала відповідає загальнолюдській, суб'єктно-вчинковій (ціннісно-мотиваційній спрямованості). Належність до яких стратегій поведінки вона виявляє, носієм яких медіа-інтроектів є. Та, врештірешт, як вона відрефлексовує реалії власної ідентичності, ймовірну свободу або ж залежність практичного пї конструювання.

Ці вміння доцільно розглядати як такі, що відповідають показникам розвитку особистості як суб'єкта вчинкового поступу, а отже, можуть слугувати критеріями суб'єктно-вчинкової зрілості молодої людини в медіапросторі.

Практика опитування засвідчує, що сьогодні топовими інформаційно-пізнавальними, емоційними джерелами масової аудиторіє є телебачення та Інтернет (вибірку респондентів склали 350 студентів гуманітарних і фізико-математичних дисциплін).

Скориставшись процедурою контент-аналізу, ми розглянули особливості морально-етичного контенту теле-медіа. Проведено аудит інформаційної політики рейтингових (за результатами респондентів) вітчизняних телеканалів (1+1, НОВИЙ, СТБ, УКРАЇНА, ІНТЕР). Основна мета вбачалася не у критиці, а, власне, в гуманітарній 
експертизі, що особливо актуально в контексті Концепції гуманітарного розвитку України, в якій апелюють до принципів людиноцентризму (максимального розвитку людського потенціалу, реалізації інтелектуальних творчих і культурних потенцій людини), як критерію оцінки зрілості суспільних інститутів тощо.

Результати психологічного моніторингу телеефіру вітчизняних телеканалів вказують на чіткі тенденції та дозованість контенту. Зокрема, підраховано, що близько 68\% телеефіру складають передачі, т/с, художні фільми, ток-шоу, реаліті-шоу, програми з негативним емоційним навантаженням (сценами насилля, агресії, містики, сексуального розбещення, уніфікованими, примітивними моделями поведінки тощо). У прайм-тайм обсяг насильства зростає на всіх каналах телебачення, демонструючи близько 5-7 жорстоких сцен на годину тощо (достатня кількість повторень для ефективності навіювання). У цьому контексті можемо говорити і про формування віктимізації.

Припускаємо, що систематичне упровадження емоційнозабарвлених, уніфікованих (спрощених) уявлень і суджень (стереотипів, чуток, міфів, іміджу) у потік «організованих» новин автоматично формує в масовій свідомості негативну або позитивну реакцію на конкретну подію або ж змінює емоційний фон цільової аудиторії. Достатньо пригадати, що події авіакатастрофи українського Boeing 737 в Ірані та пов'язані з нею резонуючі наслідки (чи, скажімо, масштабні пожежі в Австралії) впродовж місяця мас-медіа витіснили із масової свідомості небезпекою короновірусу.

Що ж стосується політичних преференцій, то розподіл синхрону політиків у новинах не завжди співвідноситься із симпатіями електорату. Результати моніторингу фіксують схильності телеканалів різних медіа-холдингів. Загалом «збалансованість новин», як і, власне, «збалансованість матеріалу» сьогодні доволі слабо відображена в медіа. Практика опитування засвідчує, що близько 90\% студентської молоді ретроспективно відтворюють медіа-новини (подіiі) насамперед негативного, фатального змісту: вбивства, теракти, катастрофи, стихійні лиха, аварії, смертельні випадки, військові конфлікти, сенсаційні злочини, соціально-політичні оказії (інфляції, дефолти) тощо. Означені факти дозволяють говорити про домінантний емоиійно інформаційний фон у суспільстві. А тому цілком логічною та послідовною видається екзистенційна фрустрація молоді, що проявляється в апатії, нудьзі, агресіі, загалом у відчутті беззмістовності й фатумі сьогодення тощо.

Водночас результати проведеного опитування засвідчують, що телебачення поступово витісняється на периферію (цільова аудиторія - 
особи похилого віку, жителі агропромислових комплексів тощо), натомість Інтернет набирає пріоритетності та переймає на себе соціалізуючу функцію підростаючої особистості (80\%) - «покоління 2020».

Подаємо ряд тенденцій, які, на наш погляд, відображають вплив інформаційно-інтерактивного поля на пізнавальну й емоційно-вольову сферу молодої людини:

- змінюється мозковий $і$ нервовий субстрат психіки, відбуваються трансформації на психофізіологічному рівні: підвищений рівень збудливості, дратівливості, нейротизму (у 70\% респондентів виявлено високий рівень особистісної тривожності за методикою Ч. Спілбергера); зміни психічної діяльності (рівень переключення уваги високий (65\% респондентів за тестом Ф. Горбова «Червоно-чорна таблиця»), натомість концентрація, стійкість, розподіл уваги - низькі (60\% респондентів за тестом «Коректурна проба»); рівень понятійного мислення низький (30\%) або середній (40\% респондентів за методикою «Складні аналогії»), конкретно-ситуативний тип мислення домінує над абстрактно-логічним (60\% за результатами тесту «Виділення суттєвих ознак»); низький рівень гнучкості мислення (65\% респондентів за методикою «Індивідуальні особливості розв'язування задач») тощо;

- формується своєрідне «рекламне мислення» - якщо доросла людина може себе захистити від впливу реклами, то дитяча психіка інтеріорізує і привласнює «рекламну» модель світу як єдино можливу; вся система дитячої психіки 3 iї формами і смислами починає будуватися за «рекламним взірцем», із позицій нейропсихології дитина повторює ментально всі ті рухи, які бачить перед собою; причиною фрустрації стає відчуття дисонансу, викликане порівнянням себе 3 рекламними моделями;

- створюється ілюзія нескінченності спілкування - феномен «мережевого спілкування» як альтернатива соціальній ізоляції; інтернет-спілкування як субкультура, створення референтної групи онлайн; результати опитувань вказують, що 95\% респондентів сьогодні не зможуть уже обійтися без цифрових медіа більше години; 80\% респондентів зауважили, що половину свого активного повсякдення проводять у режимі онлайн (5-7 годин щоденно). Можемо припустити, що найменше $40-50 \%$ студентської молоді, відмовившись від соціальних мереж, де-факто опиняться в соціальній ізоляції;

- в Інтернеті редуковані невербальні канали комунікації («мова тіла - body language»), блокується тактильний контакт; виникає проблема оперативної передачі смислу, що, у свою чергу, створює хибну атрибуцію;

- формується $i$ підтримується псевдоідентичність (соціальні мережі - це структура, що дає можливість творити нові образи 
власного «Я» т. зв. «віртуальні особистості» («onlin-persona»); он-лайн забезпечує їх втілення через можливість анонімних соціальних інтеракцій (сайти, чати, блоги);

- створюється феномен «селебрефікаиіï» - «зірковості» (модель когнітивних i поведінкових орієнтирів для решти в певному конкурентному полі; інтернет-пости, блоги - перехід із приватного в публічний сегмент інформаційного простору); Facebook / Instagram доводить, що метою є не стільки слухати / розглядати інших, як розповідати / демонструвати себе «чим більше лайків, тим вищий зірковий статус» (75\% респондентів);

- анонімність, відсутність зовнішнього контролю (право створювати й поширювати контент гарантовано Інтернетом, що навіть більш важливо, бо текст без дистрибуції немає сенсу (вірусний маркетинг).

Примітним у цьому контексті є попит, яким користуються ті об'єкти соціальної циркуляції, що максимально вправно експлуатують епатаж, енергію інстинктів. Тут первинна форма епатажу як невід'ємна, спонукальна компонента породження новітніх напрямів у мистецтві (модернізму, сюрреалізму, футуризму, дадаїзму) не актуальна. Це давно уже не спосіб самовираження чи радикальна форма вияву заперечень проти традицій i канонів. Сьогодні більшою мірою це сурогати епатажу: мотивовано зухвалі, афективно-провокаційні персонажі онлайн-ігор, асоціальні, аморальні поведінкові патерни «онлайн-героїв», медіа-сенсації, медіа-скандали, манірність селебретіс тощо. Усе це добре спланований PR-хід, гарантований спосіб стати впізнаваним, привернути до свого онлайн-продукту, онлайн-персонажу максимум уваги, інколи ціною поведінки, яка межує із психопатичними, асоціальними проявами.

Близько $80 \%$ респондентів зазначають, що їхню увагу насамперед привертають такі медіа-теми, як: розваги, сенсації, гроші, суспільні / природні катастрофи, політика. Натомість респондентам складно пригадати бодай два факти / події у сфері науки, культури чи освіти, висвітлені в мас-медіа. Зрештою, «неписане правило чотирьох «С» $\mathrm{i}$ «Г» журналістики так і зауважує: смерть, сльози, сміх, секс, гроші $є$ найбільш актуальними темами цільової аудиторії, що забезпечують рейтинг мас-медіа.

Водночас у своїх відповідях респонденти (75\%) зазначили, що, окрім розважальної функції, мас-медіа виконують для них освітню i пізнавальну функції, формують їхню думку, свідомість і позицію щодо тих чи інших суспільно-політичних подій. Це, вочевидь, дисонує 3 вищеописаною емпірикою. Припускаємо, що такий спосіб вдоволення пізнавальної та освітньої потреби молодої людини призводить до 
втрати власної індивідуальної семантики, розуміння істинної феноменології речей, явищ, фактів. Сумнівною видається спроможність молодої людини дозувати споживання медіа-інформації, а тим паче сепарувати іiі.

У цьому контексті вартою уваги бачиться філософська рефлексія М. Фуко, котрий, розглядаючи ідентичність, наголошує, що лише усвідомлення себе у взаєминах (комунікації) з різними структурами, можливість втручання у них і спроби змінити щось у них виявляють свободу й авторство конструювання власної ідентичності, свободу самому створювати себе, свободу самому знаходити для себе відповідь на питання «хто я?» «ким $є$ інші?» «яким є світ, що мене оточує?». Ця свобода апріорі притаманна словам, помислам і вчинкам людини, свобода практичного конструювання власної ідентичності у прагненні відповісти на це питання. Направді спосіб мислення, переживання, вчинення, 3 одного боку, характеризує людину, вказуючи на іï належність, а 3 іншого - щораз відкриває можливість бути іншою, знову і знову ініціюючи роботу свободи ${ }^{17}$.

Таким чином, є суттєві підстави розглядати означену проблему у суб'єктно-вчинковому вимірі, а саме - онтопсихологічному причиннонаслідковому зв’ язку. «Якщо поняття «суб'єктність» несе в собі, з одного боку, наукове знання про цілісний онтопсихологічний проект буття людини, а 3 іншого - фіксує такі сутнісні ознаки іï активності, як суб'єктність, автономність, самодетермінованість, спонтанійність, інтегративність, креативність, орієнтує у пошуку внутрішніх джерел i рушійних сил іï розвитку, підкреслює іï авторське право, спроможність починати причиновий ряд iз самої себе i нести персональну відповідальність за вдієне, то поняття «вчинковість» позначає ціннісносмисловий, індивідуально-неповторний, культурно-особистісний i, власне, душевно-духовний вектори суб'єктної активності людини в їх сутнісному вимірі» (В. Татенко) ${ }^{18}$.

Аби відстежити емпірично змістові та статусно-рольові характеристики ідентичності студентської молоді, респондентам було запропоновано тест М. Куна і Т. Макпартлена «Хто я?» (модифікація Т. Румянцевої), в якому протягом 12 хв необхідно було дати 20 відповідей на питання: «Хто я?».

За результатами дослідження 75\% респондентів виявили середній (40\%) i низький (35\%) рівень самопрезентації, минаючи позначку

${ }^{17}$ Фуко М. Археология знания / пер. с франц. М. Раковой, Ф. Серебрянниковой. Санкт-Петербург : Гуманитарная академия, 2004. С. 121-135.

18 Татенко В. Соціальна психологія впливу : монографія. Київ : Міленіум, 2008. C. 183 . 
8/10 відповідей, зазначали, що далі їм «складно відповідати», «не знають, про що писати».

Розглянуто співвідношення соціальних ролей та індивідуальних характеристик у відповідях респондентів, що засвідчує, наскільки молода людина усвідомлює і приймає свою унікальність, наскільки їй важлива належність до тієї чи іншої групи людей, а це відображає співвідношення соціальної та особистісної ідентичності. Під особистісною ідентичністю розуміли набір характеристик, який робить молоду людину схожою саму на себе і відмінною від інших, а соціальну ідентичність трактували в термінах групового членства, належності до більшої чи меншої групи людей.

Отримані результати емпіричного дослідження засвідчують, що близько $60 \%$ респондентів демонструють відсутність у самоописі індивідуальних характеристик (показників рефлексивної, комунікативної, матеріальної, діяльної ідентичностей) при вказівці безлічі соціальних ролей («дівчина / хлопець», «юнак / юнка», «студент / студентка», «громадянин / громадянка», «перехожий / перехожа», «житель / жителька планети», «частина суспільства», «християнин / християнка», «віруюча / віруючий», «герой», «ворог», «патріот», «українець / українка», «виборець», «брат / сестра», «донька / син», «волонтер», «футболіст», «співачка», «танцюристка», «математик», «історик», «журналіст» тощо).

Виявлені тенденції можуть свідчити про низький рівень саморефлексії, самопізнання, саморозкриття, дію механізмів психологічного захисту. Окрім цього, соціальна ідентичність домінує у разі, коли у людини спостерігається високий рівень визначеності схеми «ми - вони» i низький рівень визначеності схеми «я - ми», простежується т. зв. ефект «масової людини». Натомість особистісна ідентичність переважає у людей із високим рівнем визначеності схеми «я - вони» і низьким рівнем визначеності схеми «ми - вони».

Показовим у цьому контексті бачиться і такий психолінгвістичний аспект ідентичності, як валентність, під якою розуміли переважаючий емоційно-оцінний тон ідентифікаційних характеристик у самоописах респондентів. Різниця загального емоційно-оцінного знаку ідентифікаційних характеристик дозволила констатувати у відповідях студентів нейтральний тип, що спостерігається в самоідентифікаціях без яскраво вираженого емоційного тону, зокрема як формальне перерахування ролей, фізичних ознак: «донька», «староста», «раціонал», «екстраверт», «інтроверт», «флегматик», «меланхолік», «фізик», «дитина», «господар», «студент», «частина суспільства», «тіло», «істота», «людина», «особистість» тощо. Наявність нейтральної валентності може виступати ознакою дизадаптивного стану 
ідентичності, що пов'язано 3 імпульсивністю, непостійністю, тривожністю, депресивністю, вразливістю, невпевненістю у своїх силах, стриманістю, боязкістю, а також проживатися як кризовий стан, як прояв нерішучості (складно приймати рішення, втілювати задуми, багато сумнівів).

Підсумовуючи, зазначимо, що ідентичність формується в ході індивідуального розвитку і $\epsilon$ результатом психологічних процесів соціалізації, ідентифікації, особистісної інтеграції. У період швидких змін у соціокультурній системі криза ідентичності може набувати масовий характер. Усе це дає підстави для тривожних екстраполяцій на майбутне.

\section{ВИСНОВКИ}

Сьогодні мас-медіа - один із основних комунікаторів молодої людини, який перебирає на себе соціалізуючу функцію. Актуалізується проблема впливу мас-медіа, зокрема масифікації як сучасної форми «зовнішньої несвободи» i цілковитої уніфікації. Наповнюючи суспільну свідомість смисловими матрицями, що визначають поведінку й позицію молодої людини, мас-медіа реалізують функцію тотального контролю суспільно-культурного буття молодої людини. У просторі мас-медіа ця проблема виявляється в «соціальній телепатії» як формі прояву масовості, коли у молодих людей, котрі є споживачами єдиного емоційно-інформаційного простору, виникають єдині ідеї, емоції, переконання. Сумнозвісним наслідком означених процесів $\epsilon$ формування т. зв. «морально-соціального дальтонізму»: з одного боку, різниця (відмінність) між соціальними уявленнями затушовується, кордони між їх іконічним і концептуальним аспектом нівелюються, а 3 іншого - зникнення цієї відмінності та меж змінює соціальні уявлення, роблячи їх ще більшою мірою символічними.

Онлайн-медіа (інтерактивні медіа) набувають пріоритету у рейтингу особистості, яка зростає. Їх всемогутній вплив як, зрештою, й фатальні наслідки для психіки безсумнівні. У цьому інтерактивному сегменті актуальним фактором стає не стільки інформація, як увага. Тож дискусії про віковий критерій користувача Інтернетом $\epsilon$ цілком правомірними, на кшталт: «вільний доступ до інтернету має бути за паспортом».

Результати проведеного дослідження вказують на існування кризового стану ідентичності молодої людини. За основу аналізу взято методологію суб'єктно-вчинкового конструювання реальності. Відсутність знань i навичок сепарування інформації, роботи 3 інформаційними ресурсами, тобто категоризації інформації загалом, дозволяють говорити про особистісну, а отже, і суб'єктно-вчинкову 
незрілість молодої людини в медіа-просторі. Як наслідок, це ускладнює процес самокатегоризації, самоінтерпретації, нівелює рефлексію переживання власного буття, призводить до втрати внутрішнього балансу та самототожності особистості, посилює вплив і залежність від медіа, актуалізує механізми психологічного захисту і поглиблює кризу ідентичності (тенденцію знеособлення). Без перебільшення можна сказати, що сьогодні дискурс власного вибору стає риторикою особистої автономії та самовизначення молодої людини в сучасному медіа-просторі.

\section{АНОТАЦІЯ}

Розглянуто мас-медіа та феноменологію їх впливу на молоду людину як суб'єкта психічної активності, свободу конструювання власної ідентичності. Ідентичність стає тією призмою, крізь яку вивчаємо, оцінюємо соціальну сферу сучасного житття молодої людини (результати дослідження студентської молоді). Означену проблему подано у суб'єктно-вчинковому вимірі, а саме онтопсихологічному причинно-наслідковому зв'язку. Виявлено ряд трансформацій у респондентів на психофізіологічному рівні; відсутність знань i навичок роботи студентів 3 інформаційними ресурсами, сепарування медіаінформації, іiі категоризації загалом, що дозволяе говорити про особистісну, а отже, і суб'єктно-вчинкову незрілість молодої людини в медіа-просторі. Доведено низький рівень рефлексії переживання власного буття, що призводить до втрати внутрішнього балансу та самототожності юнаків / юнок, посилює вплив і залежність від медіа, актуалізує механізми психологічного захисту i поглиблює кризу ідентичності (тенденцію знеособлення).

\section{ЛІТЕРАТУРА}

1. Бахтин М. Эстетика словесного творчества / сост. С. Бочаров ; текст подгот. Г. Бернштейн и Л. Дерюгина ; примеч. С. Аверинцева и С. Бочарова. Москва : Искусство, 1986. С. 385.

2. Винтерхофф-Шпурк П. Медиапсихология. Основные принципы / пер. с нем. Харьков : Изд-во Гуманитарный центр, 2007. С. 185-186.

3. Кальба Я. Масифікація та іï прояви в контексті сучасних телемедіа. Практична психологія та соціальна робота. 2010. № 4. C. 63-64.

4. Маклюэн М. Понимание Медиа: Внешние расширение человека / пер.с англ. В. Николаева. Москва : Жуковский : КАНОН-пресс-Ц. 2003. C. $46-47$.

5. Московичи С. Век толп. Исторический трактат по психологии масс. Москва : Центр психологии и психотерапии, 1998. С. 238. 
6. Московичи С. Социальные представления : исторический взгляд. Психологический журнал. 1995. Т. 16. № 1. С. 3-13.

7. Почепцов Г. Від Facebook'y i гламуру до Wikileaks: медіакомунікації. Київ : Спадщина, 2012. С. 52.

8. Психологія мас : навчальний посібник / автор-упор. Я. Кальба. Тернопіль : Навчальна книга Богдан, 2012. 208 с.

9. Татенко В. До питання про інтимно-особистісну сферу політичного життя. Проблеми політичної психологї та ї̈ роль у становленні громадянина Української держави : збірник наукових праць / заг. ред. М.Слюсаревський та ін. Київ : Міленіум, 2008. Вип. 8. C. 14 .

10. Татенко В. Соціальна психологія впливу : монографія. Київ : Міленіум, 2008. С. 183.

11. Фрейд 3. Психоаналитические этюды. Минск : ООО «Попурри», 2001. С. 424-425.

12. Фуко М. Археология знания / пер. с франц. М. Раковой, Ф. Серебрянниковой. Санкт-Петербург : Гуманитарная академия, 2004. C. 121-135.

13. Bauman Z. The individualized society. Cambridge, Eng. : Polity Press, 2001. P. 176-183.

14. Bruhn K., Denesi M. Dictionary of Media and Communication. New York, 2009. P. 207.

Information about the author: Kalba Ya. Ye., $\mathrm{PhD}$ in Psychology, Associate Professor at the Department of Psychology Ternopil Volodymyr Hnatiuk National Pedagogical University 2, Maksyma Kryvonosa str., Ternopil, Ukraine 